Communication

\title{
Microindolinone A, a Novel 4,5,6,7-Tetrahydroindole, from the Deep-Sea-Derived Actinomycete Microbacterium sp. MCCC 1A11207
}

\author{
Siwen Niu ${ }^{1}$ (D), Ting-Ting Zhou ${ }^{1}$, Chun-Lan Xie ${ }^{1}$, Gai-Yun Zhang ${ }^{2}$ and Xian-Wen Yang ${ }^{1,2, *}$ (1) \\ 1 State Key Laboratory Breeding Base of Marine Genetic Resources, Key Laboratory of Marine Genetic \\ Resources, Third Institute of Oceanography, State Oceanic Administration, 184 Daxue Road, Xiamen 361005, \\ China; niusi123@126.com (S.N.); zhoutt@outlook.com (T.-T.Z.); xiechunlanxx@163.com (C.-L.X.) \\ 2 Fujian Key Laboratory of Marine Genetic Resources, South China Sea Bio-Resource Exploitation and \\ Utilization Collaborative Innovation Center, Third Institute of Oceanography, State Oceanic Administration, \\ 184 Daxue Road, Xiamen 361005, China; zhgyun@tio.org.cn \\ * Correspondence: yangxianwen@tio.org.cn; Tel.: +86-592-219-5319
}

Received: 25 May 2017; Accepted: 14 July 2017; Published: 19 July 2017

\begin{abstract}
A novel indole, microindolinone A (1), was isolated from a deep-sea-derived actinomycete Microbacterium sp. MCCC 1A11207, together with 18 known compounds (2-19). By detailed analysis of the ${ }^{1} \mathrm{H},{ }^{13} \mathrm{C}, \mathrm{HSQC}, \mathrm{COSY}, \mathrm{HMBC}$, high resolution electron spray ionization mass spectrum (HRESIMS), and circular dichroism (CD) data, the absolute configuration of $\mathbf{1}$ was elucidated as $5 R$-hydroxy-4,5,6,7-tetrahydroindole-4-one. It is noteworthy that $\mathbf{1}$ is the second example of a saturated indole isolated from nature.
\end{abstract}

Keywords: deep-sea; actinomycete; Microbacterium sp.; indole

\section{Introduction}

Actinomycetes are Gram-positive bacteria known for their ability to produce structurally novel secondary metabolites with various biological activities [1]. The best-known compound is salinosporamide A [2,3]. Very recently, the representative examples included pyrazolofluostatins and aminorifamycins isolated from marine Micromonospora species [4,5].

The genus Microbacterium of the Microbacteriaceae family was first proposed by Orla-Jensen in 1919. Up to now, there are 97 species reported from diverse habitats including land, ocean, air, blood, etc. However, only four compounds were reported from this genus [6,7]. In our current research for novel compounds from deep-sea-derived microorganisms [8-10], the actinomycete Microbacterium sp. MCCC 1A11207, isolated from southwestern Indian Ocean sediment, was subjected to a systematic chemical examination. Consequently, one new and 18 known compounds were obtained. Herein, we report the isolation, structural elucidation, and bioactivities of these compounds.

\section{Results and Discussion}

Microbacterium sp. MCCC 1A11207 was cultured in a 50 L fermentor containing 30 L A3 medium for 10 days. Then, the fermentation broth was centrifuged. The supernatant was extracted with EtOAc and the mycelium was extracted with $\mathrm{MeOH}$. They were concentrated and combined to give the crude extract (17 g). By repeated column chromatography (CC) over silica gel, octadecylsilyl (ODS), and Sephadex LH-20, 19 compounds were obtained (Figure 1). 
<smiles>O=C1c2cc[nH]c2CCC1O</smiles><smiles>O=C(O)c1ccc[nH]1</smiles>

2<smiles>O=C1CNC(=O)[C@H](Cc2c[nH]c3ccccc23)NC1=O</smiles><smiles>[R]c1ccc(C[C@H]2NC(=O)CNC2=O)cc1</smiles><smiles>CC(C)C[C@@H]1NC(=O)[C@@H]2C[C@@H](O)CN2C1=O</smiles><smiles>CC[C@H](I)[C@H]1NC(=O)[C@@H]2C[C@@H](O)CN2C1=O</smiles>

8<smiles>CC(I)[C@H]1NC(=O)[C@@H]2CCCN2C1=O</smiles><smiles>CC(C)C1CC[C@H]2C(=O)NCC(=O)N12</smiles><smiles>C=CC(C)NC=O</smiles>
$6 \mathrm{R}=\mathrm{H}$<smiles>Cc1c[nH]c(=O)[nH]c1=O</smiles><smiles>CCCCCOC(=O)c1ccccc1C(=O)OCCCC</smiles>

Figure 1. Compounds isolated from Microbacterium sp. MCCC 1A11207.

\subsection{Structure Elucidation}

Microindolinone A (1) was isolated as a colorless oil. The molecular formula was established as $\mathrm{C}_{8} \mathrm{H}_{9} \mathrm{NO}_{2}$ on the basis of a sodium adduct ion peak at $m / z 174.0525[\mathrm{M}+\mathrm{Na}]^{+}$in its HRESIMS, requiring five degrees of unsaturation. The ${ }^{1} \mathrm{H}-\mathrm{NMR}$ spectrum (Figure S1) exhibited two exchangeable protons at $\delta_{\mathrm{H}} 11.3\left(1 \mathrm{H}\right.$, brs, 1-NH) and $4.98(1 \mathrm{H}, \mathrm{d}, J=3.8 \mathrm{~Hz}, 5-\mathrm{OH})$, one oxygenated $s p^{3}\left(\delta_{\mathrm{H}} 4.05\right.$, $\mathrm{ddd}, J=11.6,4.5,3.8 \mathrm{~Hz}, \mathrm{H}-5)$ and two $\mathrm{sp}^{2}\left[\left(\delta_{\mathrm{H}} 6.74, \mathrm{dd}, J=2.9,2.4 \mathrm{~Hz}, \mathrm{H}-2\right)\right.$ and $\left(\delta_{\mathrm{H}} 6.25, \mathrm{dd}, J=2.9\right.$, $2.2 \mathrm{~Hz}, \mathrm{H}-3)]$ methines, together with two methylenes. The ${ }^{13} \mathrm{C}$ attached proton test (APT)-NMR spectrum (Figure S2) showed eight resonance signals involving three non-protonated carbons at $\delta_{\mathrm{C}}$ 194.1 (C-4), 143.4 (C-7a), and 118.4 (C-3a), three methines $\left(\delta_{C} 120.3 / C-2,105.2 / C-3\right.$, and 72.6/C-5), and two methylenes at $\delta_{\mathrm{C}} 33.0$ (C-6) and 21.3 (C-7) (Table 1). In the ${ }^{1} \mathrm{H}-{ }^{1} \mathrm{H}$ COSY spectrum (Figure S4), two fragments of NH-1/C-2/C-3 and OH-5/C-5/C-6/C-7 were determined on the basis of COSY correlations of $\mathrm{NH}-1\left(\delta_{\mathrm{H}} 11.3\right) / \mathrm{H}-2\left(\delta_{\mathrm{H}} 6.74\right) / \mathrm{H}-3\left(\delta_{\mathrm{H}} 6.25\right)$, and $5-\mathrm{OH}\left(\delta_{\mathrm{H}} 4.98\right) / \mathrm{H}-5\left(\delta_{\mathrm{H}} 4.05\right) / \mathrm{H}_{2}-6$ $\left(\delta_{\mathrm{H}} 1.87, \mathrm{~m} ; 2.20, \mathrm{~m}\right) / \mathrm{H}_{2}-7\left(\delta_{\mathrm{H}} 2.83, \mathrm{~m}\right)$ (Figure 2$)$. These two fragments can be connected by a $\alpha, \beta$-unsaturation ketone unit on the basis of HMBC cross-peaks (Figure S5) from $\mathrm{H}-2$ to $\mathrm{C}-3 / \mathrm{C}-3 \mathrm{a}$, H-3 to C-7a, OH-5 to C-4/C-5/C-6, and $\mathrm{H}_{2}-7$ to C-3a/C-5/C-6/C-7a (Figure 2), which established the planar structure of $\mathbf{1}$ as 5-hydroxy-4,5,6,7-tetrahydroindole-4-one.

Table 1. The ${ }^{1} \mathrm{H}(400 \mathrm{MHz})$ and ${ }^{13} \mathrm{C}(100 \mathrm{MHz})$ NMR spectroscopic data for $\mathbf{1}$ in DMSO- $d_{6}$.

\begin{tabular}{ccc}
\hline Position & $\delta_{\mathbf{C}}$, Type & $\delta_{\mathbf{H}}(\boldsymbol{J}$ in $\mathbf{H z})$ \\
\hline 1 & & $11.3, \mathrm{brs}$ \\
2 & $120.3, \mathrm{CH}$ & $6.74, \mathrm{dd}(2.9,2.4)$ \\
3 & $105.2, \mathrm{CH}$ & $6.25, \mathrm{dd}(2.9,2.2)$ \\
$3 \mathrm{a}$ & $118.4, \mathrm{C}$ & \\
4 & $194.1, \mathrm{C}$ & \\
5 & $72.6, \mathrm{CH}$ & $4.05, \mathrm{ddd}(11.6,4.5,3.8)$ \\
6 & $33.0, \mathrm{CH}_{2}$ & $1.87, \mathrm{~m} ; 2.20, \mathrm{~m}$ \\
7 & $21.3, \mathrm{CH}_{3}$ & $2.83, \mathrm{~m}$ \\
$7 \mathrm{a}$ & $143.4, \mathrm{C}$ & \\
$5-\mathrm{OH}$ & & $4.98, \mathrm{~d}(3.8)$ \\
\hline
\end{tabular}




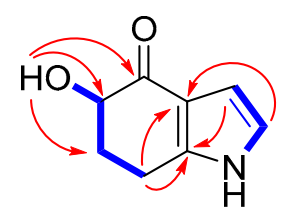

Figure 2. Key ${ }^{1} \mathrm{H}-{ }^{1} \mathrm{H}$ COSY (bold) and HMBC (arrow) correlations of $\mathbf{1}$.

The large coupling constant of $\mathrm{H}-5$ and $\mathrm{H}-6 \mathrm{a}\left(\mathrm{J}_{\mathrm{H}-5 / \mathrm{H}-6 \mathrm{a}}=11.6 \mathrm{~Hz}\right)$ indicated $\mathrm{H}-5$ as axial-orientation. In the $C D$ spectrum, the negative Cotton effect $\left(\Delta \varepsilon_{296}-0.35\right)$ induced by $\mathrm{n}-\pi^{*}$ electronic transition revealed the $R$-orientation of the 5-hydroxyl group on the basis of the octant rule (Figure 3) [11,12]. Therefore, the absolute configuration of $\mathbf{1}$ was determined as 5R-hydroxy-4,5,6,7-tetrahydroindole-4-one, and named microindolinone A. Surprisingly, although indoles occur broadly in nature [13-15], the saturated ones were seldom discovered. As a matter of fact, the only one reported was 6,7-dihydroxy-4,5,6,7-tetrahydroindole-4-one from Nocardia sp. (a soil-derived actinomycete) [16], and microindolinone A (1) was the second example. It is noteworthy that the absolute configuration of this saturated indole was determined for the first time.

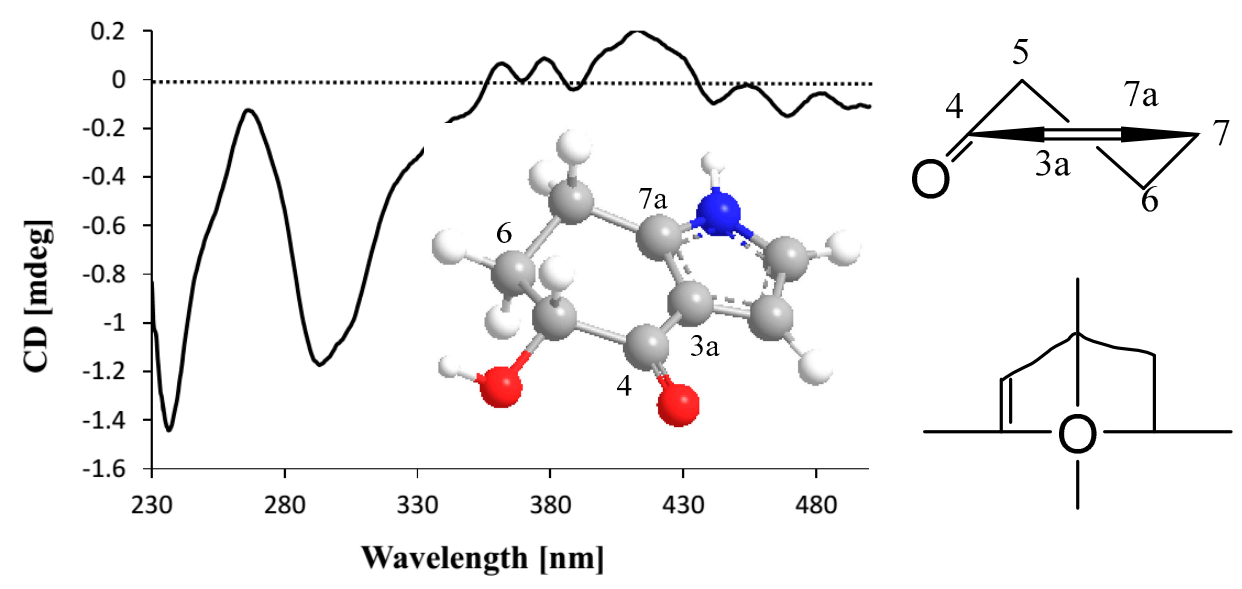

Figure 3. The $\mathrm{CD}$ spectrum in $\mathrm{CHCl}_{3}$ and octant projection of compound $\mathbf{1}$.

By comparing the ${ }^{1} \mathrm{H}-,{ }^{13} \mathrm{C}-\mathrm{NMR}, \mathrm{MS}$, and optical rotation (OR) data with those reported in the literature, 18 known compounds were identified as pyrrole-2-carboxylic acid (2) [17], cyclo(L-Trp-Gly) (3) [18], cyclo-L-Tyr-L-Pro (4) [19], cyclo(L-Trp-Gly) (5) [20], cyclo(L-Phe-Gly) (6) [21], cyclo[L-(4-hydroxyprolinyl)-L-leucine] (7) [22,23], cyclo[L-(4-hydroxyprolinyl)-L-isoleucine] (8) [24], cyclo-(L-Pro-L-Val) (9) [25], cyclo-(L-Pro-Gly) (10) [25], cyclo-(L-Leu-L-Ala) (11) [26], cyclo-(L-Val-Gly) (12) [27], 5-methyluracil (13) [26], dibutyl phthalate (14) [28], 4-hydroxyphenylacetic acid (15) [29], $\mathrm{N}$-(4-hydroxyphenyl)-acetamide (16) [30], (S)-3-hydroxy-4-(4-hydroxyphenyl)butan-2-one (17) [31], 3-hydroxy-4-(4-dihydroxyphenyl)-2-butanone (18) [32], and (5-hydroxymethyl-furan-2-yl)-methanol (19) [33]. Surprisingly, these 19 compounds were all firstly isolated from Microbacterium species.

\subsection{Anti-Proliferative Activity of $\mathbf{1}$ against RBL-2H3 Cells}

Microindolinone A (1) was tested for anti-proliferative activity against RBL-2H3 cells. Fortunately, it did not show significant cytotoxicity, even under the highest concentration of $20 \mu \mathrm{g} / \mathrm{mL}$ (Table 2). 
Table 2. Anti-proliferative activity of $\mathbf{1}$ against RBL-2H3 cells $(n=3$, means \pm SD).

\begin{tabular}{cc}
\hline Concentrations $(\mu \mathrm{g} / \mathrm{mL})$ & Cell Viability $(\%)$ \\
\hline 20 & $91 \pm 10$ \\
10 & $93 \pm 1.4$ \\
5 & $90 \pm 10$ \\
2.5 & $93 \pm 12$ \\
1.25 & $94 \pm 12$ \\
0.625 & $99 \pm 14$ \\
\hline
\end{tabular}

\subsection{Anti-Allergic Activity of $\mathbf{1}$}

Microindolinone A (1) was further subjected to anti-allergic bioactivity on IgE-mediated rat mast RBL-2H3 cells. However, it did not show any positive effects under the concentration of $20 \mu \mathrm{g} / \mathrm{mL}$, while the positive control loratadine exhibited a significant inhibition rate of $37 \%$ (Table 3).

Table 3. The Anti-allergic activity of $\mathbf{1}$ against RBL-2H3 cells $(n=3$, means \pm SD).

\begin{tabular}{ccc}
\hline Compound & Concentration $(\mu \mathrm{g} / \mathbf{m L})$ & Inhibition Rate $(\mathbf{\%})$ \\
\hline $\mathbf{1}$ & 20 & $-1.4 \pm 0.8$ \\
Loratadine & 20 & $37 \pm 5.3$ \\
\hline
\end{tabular}

\section{Materials and Methods}

\subsection{General Experimental Procedures}

HRESIMS spectra were obtained from a Xevo G2 Q-TOF mass spectrometer (Waters). Optical rotations were conducted by a Rudolph IV Autopol automatic polarimeter. NMR spectra were recorded on a Bruker $400 \mathrm{MHz}$ spectrometer. Materials for column chromatography were silica gel (Qingdao Marine Chemistry Co. Ltd., Qingdao, China), ODS (50 $\mu \mathrm{m}$, Daiso, Japan), and Sephadex LH-20 (Amersham Pharmacia Biotech AB, Uppsala, Sweden). Pre-coated silica gel plates were used for thin-layer chromatography (TLC) analysis.

\subsection{Bacterial Material}

The strain MCCC 1A11207 was isolated from a deep-sea sediment of the southwestern Indian Ocean $(-1603 \mathrm{~m})$ in 2014. By comparison of its 16S rRNA gene sequence with those of validly published names from the GenBank database via the BLAST program, the strain showed the highest similarity $(98.03 \%)$ to Microbacterium amylolyticum N5 ${ }^{\mathrm{T}}$. Therefore, it was identified to be Microbacterium sp. MCCC 1A11207. A voucher strain of the actinomycete was deposited in the Marine Culture Collection of China with the accession number of MCCC 1A11207.

\subsection{Cultivation and Extraction}

The strain was cultured on the $2216 \mathrm{E}$ medium at $28^{\circ} \mathrm{C}$ for 3 days and the colony was inoculated to $250 \mathrm{~mL}$ Erlenmeyer flasks containing $50 \mathrm{~mL} \mathrm{A3}$ medium compositing with $15 \mathrm{~g}$ bacterial peptone, $5 \mathrm{~g}$ soybean peptone, $15 \mathrm{~g}$ soluble starch, $30 \mathrm{~g}$ marine salt, and $1 \mathrm{~L}$ tap water, and then was cultured in a rotary shaker with $180 \mathrm{rpm}$ at $28^{\circ} \mathrm{C}$ for 3 days as the spores' medium. The large-scale fermentation was performed by a $50 \mathrm{~L}$ fermentor containing $30 \mathrm{~L} \mathrm{~A} 3$ medium with the $5 \%$ seed culture, and the fermentation continued at $28{ }^{\circ} \mathrm{C}$ with $180 \mathrm{rpm}$ for 10 days. Then, the fermentation broth was centrifuged $(16,000 \mathrm{rpm})$ to get supernatant and mycelium. The supernatant was extracted with EtOAc three times, and then concentrated under reduced pressure to provide the crude extract A. The mycelium was extracted with $\mathrm{MeOH}$ twice. After removing $\mathrm{MeOH}$, the residue was re-extracted with EtOAc three times to get extract B under reduced vacuum. Extracts A and B were combined to give the total crude extract. 


\subsection{Isolation and Purification}

The total crude extract (17 g) was subjected to column chromatography (CC) on ODS, eluting with a gradient $\mathrm{MeOH}-\mathrm{H}_{2} \mathrm{O}(5: 95 \rightarrow 100: 0)$ to give four fractions (Fr.1-Fr.4). Fraction Fr.2 (92 mg) was first subjected to Sephadex LH-20 CC eluting with $\mathrm{MeOH}$, and then by CC over silica gel using $\mathrm{CHCl}_{3}-\mathrm{MeOH}(100: 1)$ to provide 2 (6.8 mg). Fraction Fr.3 (283 mg) was separated by CC over Sephadex LH-20 (MeOH) to get five subfractions (Fr.3.1-Fr.3.5). Subfraction Fr.3.1 was purified by CC on silica gel eluting with petroleum ether (PE)-acetone (2:1) to get $14(11.3 \mathrm{mg})$. Compounds $12(9.2 \mathrm{mg})$ and 19 (2.3 mg) were isolated from subfraction Fr.3.2 by CC over silica gel $\left(\mathrm{CHCl}_{3}-\mathrm{MeOH}, 20: 1\right)$, while 5 $(2.1 \mathrm{mg})$ and $\mathbf{1 3}(23.0 \mathrm{mg})$ were obtained from subfraction Fr.3.5 $\left(\mathrm{CHCl}_{3}-\mathrm{MeOH}, 6: 1\right)$. Compound 10 $(38.0 \mathrm{mg}$ ) was isolated from Fr.3.3 using recrystallization in MeOH. Subfraction Fr.3.4 was subjected to CC over silica gel eluting with PE-acetone (3:1) to get 1 (1.1 mg). Fraction Fr.4 (380 mg) was fractionated by CC on Sephadex LH-20 (MeOH) to obtain five subfractions (Fr.4.1-Fr.4.5). Subfraction Fr.4.1 was subjected to CC over silica gel (PE-acetone, 2:1) to get two subfractions Fr.4.1.1 and Fr.4.1.2. Subfraction Fr.4.1.1 was purified by CC over silica gel (PE-acetone, 2:1) to get 11 (1.8 mg). Fr.4.1.2 was subjected to MPLC using gradient $\mathrm{MeOH}-\mathrm{H}_{2} \mathrm{O}(5 \rightarrow 30 \%)$ to get $7(8.0 \mathrm{mg}), 8(3.8 \mathrm{mg})$, and 9 $(8.7 \mathrm{mg})$. Fr.4.2 was purified by CC over silica gel $\left(\mathrm{CHCl}_{3}-\mathrm{MeOH}, 6: 1\right)$ to provide 16 (38.2 mg). Fr.4.3 was subjected to $\mathrm{CC}$ on silica gel $\left(\mathrm{CHCl}_{3}-\mathrm{MeOH}, 20: 1\right)$ to get two subfractions Fr.4.3.1 and Fr.4.3.2. Subfraction Fr.4.3.1 was further purified by Prep. TLC (PE-EtOAc, 1:1) to get 17 (1.2 mg) and 18 $(1.4 \mathrm{mg})$, while compounds $4(12.1 \mathrm{mg})$ and $\mathbf{6}(9.8 \mathrm{mg})$ were isolated from Fr.4.3.2 by CC over silica gel (PE-EtOAc, 1:1). Fr.4.4 and Fr.4.5 were purified by CC on silica gel eluting with PE-EtOAc (1:1) and PE-EtOAc (2:1) to get $\mathbf{1 5}(8.6 \mathrm{mg})$ and $\mathbf{3}(2.3 \mathrm{mg})$, respectively.

Microindolinone $A(\mathbf{1})$ : Colorless oil; $[\alpha]_{\mathrm{D}}^{25}+2.5(c 0.11, \mathrm{MeOH}) ; \mathrm{CD}\left(\mathrm{CHCl}_{3}\right) \lambda_{\max }(\Delta \varepsilon) 237(-0.42)$, 268 (-0.04), $296(-0.35) ;{ }^{1} \mathrm{H}$ - and ${ }^{13} \mathrm{C}-\mathrm{NMR}$ data, see Table 1 ; HRESIMS (positive) $\mathrm{m} / z$ 174.0525, calcd. for $\mathrm{C}_{8} \mathrm{H}_{9} \mathrm{NO}_{3} \mathrm{Na}^{+} 174.0531$.

\subsection{Anti-Proliferative Assay}

According to previously reported protocols [34], the cytotoxicity test was carried out using the MTT assay on RBL-2H3 cells. In brief, RBL-2H3 cells were seeded into 96-well cell culture plates. Then, six different concentrations of 1 , ranging from 0.625 to $20 \mu \mathrm{g} / \mathrm{mL}$, were added. After $24 \mathrm{~h}$, the cells were treated with $20 \mu \mathrm{L}$ MTT solution. The cytotoxicity was quantified by measuring the absorbance at $570 \mathrm{~nm}$. The cell viability was calculated using the following equation: Cell viability $(\%)=[(\mathrm{As}-\mathrm{Av}) /(\mathrm{Ac}-\mathrm{Av}) \times 100 \%$, where As is the absorbance of the sample, $\mathrm{Av}$ is the absorbance of the vehicle, and Ac is the absorbance of the control.

\subsection{Anti-Allergic Test}

The anti-allergic activity, indexed by the $\beta$-hexosaminidase release, was measured for the efficiency of the RBL-2H3 cell degranulation inhibition rate using IgE-mediated mast cell allergic reaction [8,35]. In short, RBL-2H3 cells were seeded into 96-well cell culture plates $\left(1 \times 10^{5}\right.$ cells $/$ well $)$ to incubate with dinitrophenol (DNP) specific IgE overnight. IgE-sensitized RBL-2H3 cells were pre-treated with compound $\mathbf{1}(20 \mu \mathrm{g} / \mathrm{mL})$ for $1 \mathrm{~h}$ and stimulated with dinitrophenyl-bovine serum albumin (DNP-BSA) $(500 \mathrm{ng} / \mathrm{mL})$. The negative control group was added to $200 \mu \mathrm{L}$ phosphate-buffered saline (PBS) buffer. The $\beta$-hexosaminidase activity was quantified by measuring the fluorescence intensity of the hydrolyzed substrate in a fluorometer. The degranulation efficiency was calculated using the following formula: Degranulation efficiency $(\%)=$ Fsup $/$ (Fsup + Flys $) \times 100 \%$, where Fsup is the fluorescence value of the supernatant and Flys is the fluorescence value of cell lysates. The inhibition rate was calculated based on the following formula: Inhibition rate $(\%)=($ Positive - Sample $) /($ Positive - Negative $) \times 100 \%$, where Positive is the degranulation efficiency of the DNP-BSA stimulated group, Sample is the degranulation efficiency of the sample group, and Negative is the degranulation efficiency of the vehicle group. 


\subsection{Statistical Analysis}

Anti-proliferative and anti-allergic experiments were conducted three times. Results are presented as means \pm SD. One-way analysis of variance (one-way ANOVA) comparison tests of SPSS was used to evaluate the statistical significances of the differences between experimental groups. Differences were considered statistically significant for $p<0.05$ using Duncan's multiple range tests between groups.

\section{Conclusions}

From the deep-sea-derived rare actinomycete Microbacterium sp. MCCC 1A11207, 19 secondary metabolites were isolated and identified. The new compound, microindolinone A (1), was determined as $5 R$-hydroxy-4,5,6,7-tetrahydroindole-4-one. It was the second example of the tetrahydroindole found in nature. Its absolute configuration was determined for the first time.

Supplementary Materials: The following documents are available online at www.mdpi.com/1660-3397/15/7/ $230 / \mathrm{s} 1$.

Acknowledgments: The work was supported by the Science \& Technology Research Program of Fujian Province, China (2017Y0060) and the National Natural Science Foundation of China (41676130, 41606185 and 21372233). We thank Qingmei Liu and Guangming Liu of the Jimei University for biological tests.

Author Contributions: Xian-Wen Yang designed the project; Siwen Niu, Ting-Ting Zhou and Chun-Lan Xie performed experiments; Gai-Yun Zhang isolated and identified the actinomycete; Siwen Niu and Xian-Wen Yang analyzed the data and wrote the paper, while critical revision of the publication was performed by all authors.

Conflicts of Interest: The authors declare no conflict of interest.

\section{References}

1. Diminic, J.; Starcevic, A.; Lisfi, M.; Baranasic, D.; Gacesa, R.; Hranueli, D.; Long, P.F.; Cullum, J.; Zucko, J. Evolutionary concepts in natural products discovery: What actinomycetes have taught us. J. Ind. Microbiol. Biotechnol. 2014, 41, 211-217. [CrossRef] [PubMed]

2. Feling, R.H.; Buchanan, G.O.; Mincer, T.J.; Kauffman, C.A.; Jensen, P.R.; Fenical, W. Salinosporamide A: A highly cytotoxic proteasome inhibitor from a novel microbial source, a marine bacterium of the new genus salinospora. Angew. Chem. Int. Ed. Engl. 2003, 42, 355-357. [CrossRef] [PubMed]

3. Jensen, P.R.; Moore, B.S.; Fenical, W. The marine actinomycete genus Salinispora: A model organism for secondary metabolite discovery. Nat. Prod. Rep. 2015, 32, 738-751. [CrossRef] [PubMed]

4. Zhang, W.; Yang, C.; Huang, C.; Zhang, L.; Zhang, H.; Zhang, Q.; Yuan, C.S.; Zhu, Y.; Zhang, C. Pyrazolofluostatins A-C, pyrazole-fused benzo[a]fluorenes from South China Sea-derived Micromonospora rosaria SCSIO N160. Org. Lett. 2017, 19, 592-595. [CrossRef] [PubMed]

5. Williams, D.E.; Dalisay, D.S.; Chen, J.; Polishchuck, E.A.; Patrick, B.O.; Narula, G.; Ko, M.; Av-Gay, Y.; Li, H.; Magarvey, N.; et al. Aminorifamycins and sporalactams produced in culture by a Micromonospora sp. isolated from a Northeastern-Pacific marine sediment are potent antibiotics. Org. Lett. 2017, 19, 766-769. [CrossRef] [PubMed]

6. Gao, S.; Huang, R.; Zhu, S.; Li, H.; Zheng, G. Identification and characterization of a novel (+)- $\gamma$-lactamase from Microbacterium hydrocarbonoxydans. Appl. Microbiol. Biotechnol. 2016, 100, 9543-9553. [CrossRef] [PubMed]

7. Liu, D.; Lin, H.; Proksch, P.; Tang, X.; Shao, Z.; Lin, W. Microbacterins A and B, new peptaibols from the deep sea actinomycete Microbacterium sediminis sp. nov. YLB-01(T). Org. Lett. 2015, 17, 1220-1223. [CrossRef] [PubMed]

8. Xie, C.L.; Liu, Q.; Xia, J.M.; Gao, Y.; Yang, Q.; Shao, Z.Z.; Liu, G.; Yang, X.W. Anti-allergic compounds from the deep-sea-derived actinomycete Nesterenkonia flava MCCC 1K00610. Mar. Drugs 2017, 15, 71. [CrossRef] [PubMed]

9. Niu, S.; Si, L.; Liu, D.; Zhou, A.; Zhang, Z.; Shao, Z.; Wang, S.; Zhang, L.; Zhou, D.; Lin, W. Spiromastilactones: A new class of influenza virus inhibitors from deep-sea fungus. Eur. J. Med. Chem. 2016, 108, 229-244. [CrossRef] [PubMed] 
10. Yang, X.W.; Peng, K.; Liu, Z.; Zhang, G.Y.; Li, J.; Wang, N.; Steinmetz, A.; Liu, Y. Strepsesquitriol, a rearranged zizaane-type sesquiterpenoid from the deep-sea-derived actinomycete Streptomyces sp. SCSIO 10355. J. Nat. Prod. 2013, 76, 2360-2363. [CrossRef] [PubMed]

11. Sun, Y.; Tian, L.; Huang, J.; Ma, H.Y.; Zheng, Z.; Lv, A.L.; Yasukawa, K.; Pei, Y.H. Trichodermatides A-D, novel polyketides from the marine-derived fungus Trichoderma reesei. Org. Lett. 2008, 10, 393-396. [CrossRef] [PubMed]

12. Kirk, D.N. The chiroptical properties of carbonyl compounds. Tetrahedron 1986, 42, 777-818. [CrossRef]

13. Netz, N.; Opatz, T. Marine indole alkaloids. Mar. Drugs 2015, 13, 4814-4914. [CrossRef] [PubMed]

14. Ishikura, M.; Abe, T.; Choshi, T.; Hibino, S. Simple indole alkaloids and those with a non-rearranged monoterpenoid unit. Nat. Prod. Rep. 2013, 30, 694-752. [CrossRef] [PubMed]

15. Gupta, L.; Talwar, A.; Chauhan, P.M. Bis and tris indole alkaloids from marine organisms: new leads for drug discovery. Curr. Med. Chem. 2007, 14, 1789-1803. [CrossRef] [PubMed]

16. Henne, P.; Zeeck, A.; Grabley, S.; Thiericke, R. Secondary metabolites by chemical screening.35. 6,7-Dihydroxy-4,5,6,7-tetrahydroindole-4-one, a new type of indole-derivative from Nocardia sp. Nat. Prod. Lett. 1997, 10, 43-47. [CrossRef]

17. Dietera, A.; Hamm, A.; Fiedler, H.P.; Goodfellow, M.; Muller, W.E.; Brun, R.; Beil, W.; Bringmann, G. Pyrocoll, an antibiotic, antiparasitic and antitumor compound produced by a novel alkaliphilic Streptomyces strain. J. Antibiot. 2003, 56, 639-646. [CrossRef] [PubMed]

18. Deslauriers, R.; Grzonka, Z.; Schaumburg, K.; Shiba, T.; Walter, R. Carbon-13 nuclear magnetic resonance studies of the conformations of cyclic dipeptides. J. Am. Chem. Soc. 1975, 97, 5093-5100. [CrossRef] [PubMed]

19. Thajudeen, H.; Park, K.; Moon, S.-S.; Hong, I.S. An efficient green synthesis of proline-based cyclic dipeptides under water-mediated catalyst-free conditions. Tetrahedron Lett. 2010, 51, 1303-1305. [CrossRef]

20. Mollica, A.; Costante, R.; Fiorito, S.; Genovese, S.; Stefanucci, A.; Mathieu, V.; Kiss, R.; Epifano, F. Synthesis and anti-cancer activity of naturally occurring 2,5-diketopiperazines. Fitoterapia 2014, 98, 91-97. [CrossRef] [PubMed]

21. Nakao, M.; Toriuchi, Y.; Fukayama, S.; Sano, S. Synthesis and conformational characterization of diketopiperazines bearing a benzyl moiety. Chem. Lett. 2014, 43, 340-342. [CrossRef]

22. Ienaga, K.; Nakamura, K.; Goto, T. Bioactive compounds produced in animal tissues. I. Two diketopiperidine plant-growth regulators containing hydroxyproline isolated from rabbit skin tissue extract. Tetrahedron Lett. 1987, 28, 1285-1286. [CrossRef]

23. Cronan, J.M., Jr.; Davidson, T.R.; Singleton, F.L.; Colwell, R.R.; Cardellina, J.H., II. Plant growth promoters isolated from a marine bacterium associated with Palythoa sp. Nat. Prod. Lett. 1998, 11, 271-278. [CrossRef]

24. Maurer, G.; Kiechel, J.R. Ergopeptide Alkaloids. Patent DE2805977A1, 1978.

25. Hendea, D.; Laschat, S.; Baro, A.; Frey, W. Diastereoselective alkylation of a proline-derived bicyclic lactim ether. Helv. Chim. Acta 2006, 89, 1894-1909. [CrossRef]

26. Ding, Z.G.; Zhao, J.Y.; Yang, P.W.; Li, M.G.; Huang, R.; Cui, X.L.; Wen, M.L. ${ }^{1} \mathrm{H}$ and ${ }^{13} \mathrm{C}$ NMR assignments of eight nitrogen containing compounds from Nocardia alba sp.nov (YIM 30243T). Magn. Reson. Chem. 2009, 47, 366-370. [CrossRef] [PubMed]

27. Lankiewicz, L.; Nyasse, B.; Fransson, B.; Grehn, L.; Ragnarsson, U. Synthesis of amino acid derivatives substituted in the backbone with stable isotopes for application in peptide synthesis. J. Chem. Soc. Perkin Trans. 1 1994, 17, 2503-2510. [CrossRef]

28. McNulty, J.; Nair, J.J.; Cheekoori, S.; Larichev, V.; Capretta, A.; Robertson, A.J. Scope and mechanistic insights into the use of tetradecyl(trihexyl)phosphonium bistriflimide: A remarkably selective ionic liquid solvent for substitution reactions. Chem. A Eur. J. 2006, 12, 9314-9322. [CrossRef] [PubMed]

29. Milne, J.E.; Storz, T.; Colyer, J.T.; Thiel, O.R.; Dilmeghani Seran, M.; Larsen, R.D.; Murry, J.A. Iodide-catalyzed reductions: Development of a synthesis of phenylacetic acids. J. Org. Chem. 2011, 76, 9519-9524. [CrossRef] [PubMed]

30. Lin, Z.J.; Lu, X.M.; Zhu, T.J.; Fang, Y.C.; Gu, Q.Q.; Zhu, W. GPR12 Selections of the metabolites from an endophytic Streptomyces sp. asociated with Cistanches deserticola. Arch. Pharmacal Res. 2008, 31, 1108-1114. [CrossRef] [PubMed]

31. Peng, X.P.; Wang, Y.; Liu, P.P.; Hong, K.; Chen, H.; Yin, X.; Zhu, W.M. Aromatic compounds from the halotolerant fungal strain of Wallemia sebi PXP-89 in a hypersaline medium. Arch. Pharmacal Res. 2011, 34, 907-912. [CrossRef] [PubMed] 
32. Kennedy, M.L. Phytochemical profile of the stems of Aeonium lindleyi. Rev. Bras. Farmacogn. 2012, 22, 676-679. [CrossRef]

33. Goswami, S.; Dey, S.; Jana, S. Design and synthesis of a unique ditopic macrocyclic fluorescent receptor containing furan ring as a spacer for the recognition of dicarboxylic acids. Tetrahedron 2008, 64, 6358-6363. [CrossRef]

34. Yang, X.W.; Zeng, H.W.; Liu, X.H.; Li, S.M.; Xu, W.; Shen, Y.H.; Zhang, C.; Zhang, W.D. Anti-inflammatory and anti-tumour effects of Abies georgei extracts. J. Pharm. Pharmacol. 2008, 60, 937-941. [CrossRef] [PubMed]

35. Liu, Q.; Wang, Y.; Cao, M.; Pan, T.; Yang, Y.; Mao, H.; Sun, L.; Liu, G. Anti-allergic activity of R-phycocyanin from Porphyra haitanensis in antigen-sensitized mice and mast cells. Int. Immunopharmacol. 2015, 25, 465-473. [CrossRef] [PubMed]

(C) 2017 by the authors. Licensee MDPI, Basel, Switzerland. This article is an open access article distributed under the terms and conditions of the Creative Commons Attribution (CC BY) license (http:/ / creativecommons.org/licenses/by/4.0/). 